\title{
Pengaruh Model Pembelajaran Kooperatif Tipe Investigasi Kelompok terhadap Pemecahan Masalah Matematis Siswa Kelas VIII MTsN Kota Padang
}

\author{
Ramon Muhandas \\ Program Studi Pendidikan Matematika, Fakultas Tarbiyah dan \\ Keguruan, UIN Sultan Syarif Kasim Riau \\ Email: ramonmuhan2@gmail.com
}

\begin{abstract}
ABSTRAK. Penelitian ini bertujuan untuk mengetahui pengaruh penerapan model pembelajaran kooperatif tipe investigasi kelompok terhadap kemampuan pemecahan masalah matematis siswa kelas VIII MTsN Kota Padang. Jenis Penelitian ini adalah quasi experiment. Populasi penelitian ini adalah seluruh siswa kelas VIII MTsN kota Padang yang berakreditasi B dan nilai rata-rata UN matematika 2012/2013 yang berkualifikasi B serta selain kelas unggul. Teknik yang digunakan untuk pengambilan sampel adalah ramdom sampling. Sampel pada penelitian ini adalah siswa kelas VIII.1 MTsN Kota Tangah sebagai kelas eksperimen dan siswa kelas VIII.7 sebagai kelas kontrol. Instrumen yang digunakan adalah tes yang terdiri dari tes kemampuan awal untuk melihat kemampuan awal siswa dan tes akhir untuk melihat kemampuan pemecahan masalah matematis siswa. Berdasarkan hasil penelitian, diperoleh beberapa kesimpulan. Pertama, kemampuan pemecahan masalah matematis siswa yang diajar dengan model pembelajaran kooperatif tipe Investigasi Kelompok lebih baik daripada siswa yang diajar dengan pembelajaran konvensional. Kedua, kemampuan pemecahan masalah matematis siswa berkemampuan awal tinggi, sedang dan rendah yang diajar dengan model pembelajaran kooperatif tipe investigasi kelompok lebih baik daripada siswa yang diajar dengan pembelajaran konvensional.
\end{abstract}

Kata kunci : model pembelajaran kooperatif, tipe investigasi kelompok, pemecahan masalah matematis. 


\section{PENDAHULUAN}

Tujuan yang dicapai dalam pelajaran matematika menurut National Council of Teacher Of Mathematics (NCTM) tahun 2000 adalah siswa harus memiliki lima kemampuan matematis, satu diantaranya adalah: belajar untuk memecahkan masalah (mathematical problem solving).Senada dengan itu, dalam Permendiknas No.22 tahun 2006 tentang Standar Isi dinyatakan bahwa pembelajaran matematika untuk semua jenjang pendidikan dasar dan menengah bertujuan agar siswa memiliki seperangkat kompetensi atau kemampuan. Kemampuan itu salah satunya adalah kemampuan siswa memecahkan masalah yaitu kemampuan memahami masalah, kemampuan mengomunikasikan gagasan dengan simbol, tabel, diagram atau media lain untuk memperjelas keadaan atau masalah dalam hal ini dalam bentuk merepresentasikan persoalan matematika.

Berdasarkan hal tersebut jelas bahwa seorang guru harus bisa mengembangkan kemampuan matematis siswa. Kemampuan matematis yang akan dibahas pada penelitian ini adalah kemampuan siswa memecahkan suatu masalah. Kemampuan pemecahan masalah sangat penting dimiliki siswa karena akan berdampak baik dalam kehidupan mereka menyelesaikan masalah yang berkaitan dengan matematika pada kehidupan sehari-hari serta bisa bertindak cepat dan tepat dalam mengambil keputusan.

Selanjutnya Polya (Fonna, 2013) mengemukakan bahwa dalam pemecahan masalah hendaknya kita harus mencoba dan terus mencoba untuk menemukan solusi. Pemecahan masalah dapat dipertimbangkan sebagai suatu proses penyampaian tujuan pengetahuan yang baru atau suatu situasi yang unfamiliar untuk meningkatkan pengetahuan. Pentingnya kemampuan pemecahan masalah yang telah dikemukan tersebut seharusnya membuat siswa termotivasi untuk meningkatkan kemampuan mereka dalam penyelesaian masalah matematika.

Namun faktanya terdapat kesenjangan antara tujuan yang diharapkan dengan temuan-temuan yang didapat oleh penulis, diantaranya hasil PISA tahun 2009 yang menyatakan kemampuan pemecahan masalah siswa Indonesia masih tergolong rendah yaitu berada diperingkat 61 dari 65 negara peserta. Selain hasil PISA, hasil analisis literasi yang dilakukan Fauzan (2012) pada SMP/MTs di Sumatera Barat menunjukkan hal yang sama yaitu kemampuan pemecahan masalah masih banyak yang mendapatkan skor rendah yang mencapai $41 \%$ untuk kemampuan pemecahan masalah. Dan juga hasil observasi awal yang dilakukan penulis pada beberapa MTsN Kota Padang yang menunjukan bahwa kemampuan pemecahan masalah siswa 
masih tergolong rendah. Ini ditunjukkan dari ketidakmampuan siswa menjawab soal yang berupa soal pemecahan masalah.

Ketidakberhasilan tujuan dari suatu proses pembelajaran matematika bukan hanya disebabkan karena matematika yang sulit, melainkan disebabkan oleh beberapa faktor yang meliputi siswa itu sendiri, guru, metode/media pembelajaran, maupun lingkungan belajar yang saling berhubungan satu sama lain. Dalam hal ini peneliti memfokuskan kepada metode pembelajaran.

Berdasarkan hasil pengamatan dibeberapa MTsN di kota Padang, kegiatan pembelajaran dikelas masih didominasi oleh guru, walaupun ada sebagian guru MTsN di kota Padang yang sudah mulai menerapkan sistem diskusi namun proses diskusi belum bisa mengoptimalkan kemampuan mengembangkan ide-ide mereka sehingga dapat memecahkan persoalan non rutin atau kemampuan pemecahan masalah matematis.

Berdasarkan fenomena-fenomena yang terjadi di lapangan yang telah dijelaskan sebelumnya, maka guru dituntut untuk dapat melakukan perbaikan. Salah satu yang dapat dilakukan oleh guru adalah menerapkan strategi mengajar yang baik sehingga dapat mendukung keberhasilan proses pembelajaran. Belajar yang efisien dapat tercapai apabila dapat mengunakan strategi belajar yang tepat. Strategi belajar diperlukan untuk dapat mencapai hasil yang semaksimal mungkin. Namun dalam proses pembelajaran yang baik, pembelajaran tidak hanya terfokus kepada guru saja (teacher centered), tapi siswa harus lebih berperan aktif (student centered), dimana guru hanya sebagai motivator dan yang banyak aktif adalah murid. Salah satu pembelajaran yang menuntut keaktifan siswa serta kekompokan siswa adalah pembelajarankooperatif tipe investigasi kelompok.

Metode investigasi kelompok ini adalah salah satu metode spesialisasi tugas yang memberikan kesempatan pada siswa untuk mengembangkan kreativitas dan produktivitas berpikir. Siswa dilibatkan sejak perencanaan, baik dalam menentukan topik maupun cara untuk mempelajarinya melalui kegiatan investigasi. Secara umum metode investigasi sebenarnya dapat dipandang sebagai metode belajar "pemecahan masalah" atau metode belajar "penemuan". Metode pembelajaran investigasi kelompok mengharuskan guru menyiapkan masalah untuk siswa. Siswa kemudian diarahkan kepada menemukan konsep atau prinsip, karena siswa secara bersama-sama menemukan konsep atau prinsip, maka diharapkan konsep tersebut tertanam dengan baik pada diri siswa yang pada akhirnya siswa menguasai konsep atau prinsip yang baik pula, dan mampu merepresentasikan ide-ide mereka dengan baik serta dengan menguasai konsep dan mampu merepresentasikannya 
diharapkan siswa juga memiliki kemampuan pemecahan masalah yang baik pula (Slavin, 2005).

Investigasi itu sendiri secara bahasa adalah penyelidikan dengan mencatat atau merekam fakta, melakukan peninjauan, percobaan, dan sebagainya dengan tujuan memperoleh jawaban atas pertanyaan (KBBI online). Sementara Bastow menjelaskan investigasi kelompok adalah suatu model pembelajaran yang dapat mendorong suatu aktivitas percobaan (experiment), mengumpulkan data, melakukan observasi, mengidentifikasi suatu pola, membuat dan menguji kesimpulan/dugaan (conjecture) dan membuat suatu generalisasi (Lidinillah, 2009).

Faktor yang juga menentukan keberhasilan siswa dalam menerima pelajaran adalah kemampuan awal. Dengan melihat kemampuan awal siswa, dapat diketahui sejauh mana siswa telah mengetahui materi yang telah disajikan. Seperti yang ditegaskan dalam Permendiknas (2005) bahwa kemampuan awal siswa penting untuk diketahui guru sebelum ia mulai dengan pembelajarannya, karena dengan demikian dapat diketahui :a) apakah siswa telah mempunyai pengetahuan yang merupakan prasyarat untuk mengikuti pembelajaran; b) sejauh mana siswa telah mengetahui materi apa yang akan disajikan.

Berdasarkan uraian yang telah dipaparkan, maka rumusan masalah pada penelitian iini adalah "apakah kemampuan pemecahan masalah matematis siswa baik secara (1) keseluruhan, (2) siswa berkemampuan awal tinggi, (3) siswa berkemampuan awal sedang, dan (4) siswa berkemampuan awal rendah yang diajar dengan model kooperatif tipe investigasi kelompok lebih baik daripada siswayang diajar dengan pembelajaran konvensional?"

\section{METODE PENELITIAN}

Penelitian ini dirancang dengan menggunakan metode quasi experiment dengan rancangan penelitian yang digunakan adalah randomized control group only design. Pada penelitian ini perlakuan yang diberikan pada kelas eksperimen adalah penerapan model kooperatif tipe investigasi kelompok terhadap kemampuan pemecahan masalah matematis siswa, sedangkan pada kelas kontrol menggunakan pembelajaran konvensional.

Populasi pada penelitian ini adalah siswa kelas VIII MTsN kota Padang yang berakreditasi B dan nilai rata-rata UN matematika berkualifikasi B. Selanjutnya dilakukan pengambilan sampel dengan ketentuan populasi mempunyai kesamaan rata-rata, maka terpilih secara acak kelas VIII.1 MTsN Koto Tangah sebagai kelas eksperimen dan kelas VIII.7 MTsN Durian Tarung sebagai kelas kontrol. 
Instrumen yang dikembangkan dalam penelitian ini adalah: (1) tes kemampuan awal, (2) tes akhir berupa kemampuan pemecahan masalah. Agar kualitas tes baik dan dapat mengukur kemampuan yang diinginkan.hal-hal yang dilakukan adalah membuat kisi-kisi soal, menvalidasi soal kepada beberapa ahli, melakukan ujicoba soal tes. Setelah soal diujicobakan yaitu pada kelas VIII.2 MTsN Lubuk Buaya dilakukan analisis item yaitu: (1) validitas,(2)daya beda, (3) indeks kesukaran, dan (4) reliabilitas tes. Analisis validitas item menggunakan rumus korelasi product moment, dan reliabilitas menggunakan rumus alpha, sedangkan rumus daya beda dan indeks kesukaran yang dipakai adalah untuk essay.

Berdasarkan analisis yang dilakukan terhadap soal uji coba tes kemampuan awal diperoleh bahwa semua soal dinyatakan valid, signifikan dan indeks kesukaran berada pada kategori sedang. Dengan demikian soal bisa dipakai.Selanjutnya hasil perhitungan reliabilitas tes kemampuan awal diperoleh $r_{11}=0,74$ yang berada pada kategori tinggi.Setelah soal dianalisis, soal diberikan kepada kelas eksperimen dan kontrol untuk mengetahui kemampuan awal siswa yang tergolong tinggi, sedang, dan rendah.dengan Kriteria yang dapat dilihat pada Tabel 1.

Tabel 1. Kriteria Pengelompokan Kemampuan Awal

\begin{tabular}{|c|c|}
\hline Kriteria K. Awal (KA) & Ket \\
\hline$x \geq(\bar{x}+S D)$ & Tinggi \\
\hline$(\bar{x}-S D)<x<(\bar{x}+S D)$ & Sedang \\
\hline$x \leq(\bar{x}-S D)$ & Rendah \\
\hline
\end{tabular}

Dari hasil perhitungan yang telah dilakukan diperoleh kemampuan awal (KA) pada kelas eksperimen adalah KA tinggi ada 7 siswa, sedang ada 24 siswa, dan rendah ada 6 siswa. Sedangkan pada kelas kontrol, KA tinggi ada 8 siswa, sedang ada 30 siswa, dan rendah ada 11 siswa.

Analisis soal juga dilakukan pada tes akhir yaitu yang terdiri dari 3 soal tes kemampuan pemecahan masalah yang disusun berdasarkan indikator. Setelah dilakukan ujicoba soal, diperoleh hasil tes kemampuan pemecahan masalah valid, signifikan, dan indeks kesukarannya berada pada taraf sedang. Dengan demikian, berdasarkan kriteria penerimaan soal, soal kemampuan pemecahan masalah semuanya bisa dipakai. Dan untuk reliabilitas tes kemampuan pemecahan masalah memiliki reliabilitas $r_{11}=0,51$ yang berada pada kategori sedang.

Data-data yang diperoleh selama penelitian dianalisis dengan tujuan untuk mengetahui apakah rata-rata skor kemampuan pemecahan masalah 
kelas eksperimen lebih baik daripada kelas kontrol. Sebelum melakukan uji statistik yang akan digunakan, maka terlebih dahulu dilakukan uji prasyarat yaitu uji kenormalan data dan uji homogenitas data. Jika data normal dan homogen, maka uji statistiknya yang digunakan adalah uji t, apabila tidak homogen uji t'. Sedangkan jika data tidak berdistribusi normal, maka pengujiannya menggunakan statistik non-parametrik yaitu dengan uji Mann Whitney $U$.

Berdasarkan hasil uji prasyarat, maka pengujian hipotesis untuk rumusan masalah 2 menggunakan uji Mann Whitney $U$ sedangkan hipotesis untuk rumusan masalah 1,3, dan 4 menggunakan uji $t$.

\section{HASIL PENELITIAN DAN PEMBAHASAN}

Hasil dari analisis rata-rata skor dan simpangan baku kemampuan pemecahan masalah dapat dilihat pada Tabel 2 berikut:

Tabel 2. Hasil Analisis Data Tes Kemampuan Pemecahan Masalah

\begin{tabular}{|c|l|c|c|c|}
\hline \multirow{3}{*}{ Kelas } & $\begin{array}{c}\text { Kemam-puan } \\
\text { Awal }\end{array}$ & \multirow{2}{*}{$\mathbf{N}$} & \multicolumn{2}{c|}{$\begin{array}{c}\text { Skor tes Akhir } \\
\text { Pemecahan Masalah }\end{array}$} \\
\cline { 3 - 5 } & & & $\overline{\boldsymbol{x}}$ & $\boldsymbol{s}$ \\
\hline \multirow{5}{*}{ Eksperimen } & Tinggi & 7 & 26,29 & 4,42 \\
\cline { 2 - 5 } & Sedang & 24 & 19,38 & 6,16 \\
\cline { 2 - 5 } & Rendah & 6 & 18,83 & 4,35 \\
\cline { 2 - 5 } & Keseluruhan & 37 & 20,59 & 6,15 \\
\hline \multirow{5}{*}{ Kontrol } & Tinggi & 8 & 13,38 & 3,46 \\
\cline { 2 - 5 } & Sedang & 30 & 10,63 & 5,41 \\
\cline { 2 - 5 } & Rendah & 11 & 10,18 & 4,60 \\
\cline { 2 - 5 } & Keseluruhan & 49 & 10,97 & 5,00 \\
\hline
\end{tabular}

Pada Tabel 2 terlihat bahwa rata-rata skor kemampuan pemecahan masalah siswa baik secara keseluruhan, maupun berdasarkan kemampuan awal tinggi, sedang, dan rendah pada kelas eksperimen lebih tinggi dibandingkan rata-rata kelas kontrol.

Pada Tabel 2 juga terlihat simpangan baku skor secara keseluruhan kelas eksperimen lebih tinggi dibandingkan dengan kelas kontrol. Hal ini berarti kemampuan pemecahan masalah matematis siswa kelas eksperimen lebih beragam daripada kelas kontrol. Simpangan baku skor tes pemecahan masalah pada siswa berkemampuan awal tinggi dan sedang pada kelas eksperimen lebih tinggi daripada kelas kontrol, hal ini berarti kemampuan 
pemecahan masalah matematis siswa berkemampuan awal tinggi dan sedang pada kelas eksperimen lebih beragam daripada kelas kontrol. Namun pada simpangan baku skor tes pada siswa berkemampuan awal rendah pada kelas kontrol lebih tinggi daripada kelas eksperimen, hal ini berarti bahwa kemampuan pemecahan masalah matematis siswa berkemampuan awal rendah pada kelas kontrol lebih beragam daripada kelas eksperimen.

Hasil rerata skor perindikator kemampuan pemecahan masalah matematis menunjukan bahwa kelas eksperimen lebih baik daripada kelas kontrol. Hal ini dapat dilihat pada gambar berikut :

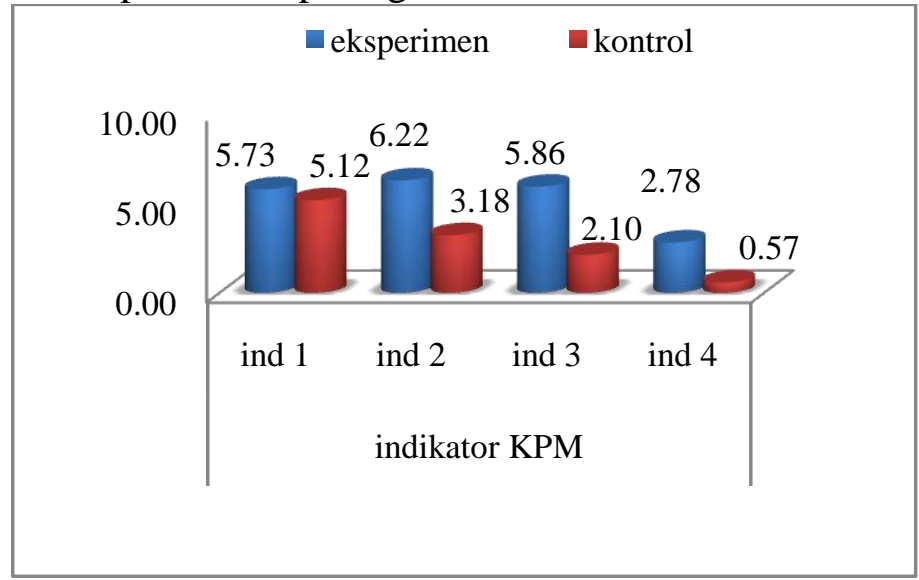

Gambar 1. Rata-rata Skor Perindikator Kem. Pemecahan Masalah Kelas Sampel

Hasil pengujian hipotesis pada kemampuan pemecahan masalah dapat dilihat pada Tabel 3 dan Tabel 4 berikut ini.

Tabel 3. Hasil Uji Hipotesis dengan Uji Mann Whitney $U$

\begin{tabular}{|l|c|c|c|c|}
\hline \multirow{3}{*}{ Hipotesis 2 } & Kelas & KA & $\mathbf{N}$ & Sig. \\
\cline { 2 - 4 } & Eks & Tinggi & 7 & \multirow{2}{*}{0,001} \\
\cline { 2 - 4 } & Kontrol & Tinggi & 8 & \\
\hline
\end{tabular}

Tabel 4. Hasil Uji Hipotesis dengan Uji $t$

\begin{tabular}{|c|l|c|c|c|}
\hline \multirow{3}{*}{ Hipotesis 1 } & Kelas & KA & N & Sig. \\
\cline { 2 - 4 } & Eks & - & 37 & \multirow{2}{*}{0,000} \\
\cline { 2 - 4 } & Kontrol & - & 49 & \\
\hline \multirow{2}{*}{ Hipotesis 3 } & Eks & Sedang & 24 & \multirow{2}{*}{0,000} \\
\cline { 2 - 4 } & Kontrol & Sedang & 30 & \\
\hline
\end{tabular}




\begin{tabular}{|l|l|c|c|c|}
\hline \multirow{2}{*}{ Hipotesis 4 } & Eks & Rendah & 6 & \multirow{2}{*}{0,001} \\
\cline { 2 - 4 } & Kontrol & Rendah & 11 & \\
\hline
\end{tabular}

Pada Tabel 3 dan Tabel 4 terlihat bahwa hasil sig $<$ taraf nyata $(\alpha=$ $0,05)$ untuk semua data. Hal ini menunjukan bahwa: kemampuan pemecahan masalah matematis siswa baik secara keseluruhan maupun berdasarkan kemampuan awal tinggi, sedang, dan rendah yang diajar dengan model pembelajaran kooperatif tipe Investigasi lebih baik daripada siswa yang diajar dengan model pembelajaran konvensional.

Kemampuan pemecahan masalah matematis siswa lebih baik pada kelas eksperimen dikarenakan model pembelajaran kooperatif tipe investigasi kelompok menuntut siswa lebih aktif mencari suatu penyelesaian dari suatu masalah secara berkelompok. Hal itu sesuai dengan dikatakan Setiawan (2006) yang dapat disimpulkan bahwa investigasi mendorong siswa untuk belajar lebih aktif dan lebih bermakna artinya siswa dituntut selalu berfikir tentang suatu persoalan dan mereka mencari sendiri cara penyelesaiannya, dengan demikian mereka akan lebih terlatih untuk menggunakan keterampilan mereka dalam menyelesaikan suatu masalah.

Selain itu, sesuai dengan konsep dasar investigasi yaitu siswa diminta membaca, menerjemahkan maksud dari topik/masalah, dan memahaminya lalu memecahkan masalah yang sedang mereka hadapi (Setiawan, 2006) . Dari konsep investigasi tersebut jelas bahwa investigasi kelompok mengajarkan siswa terbiasa memamahmi suatu permasalahan sampai memecahkan masalah tersebut. Kegiatan seperti itu pada tahapan investigasi ada pada tahap analisis dan sintesis.

Pada tahap menganalisis dan mensintesis permasalahan yang ada pada LKS, siswa belajar menemukan secara berkelompok konsep yang ingin dicapai setelah pembelajaran itu berakhir, misalnya saja siswa menganalisis suatu bentuk lingkaran dengan berbagai ukuran sehingga nantinya mereka menemukan sendiri konsep keliling lingkaran tersebut. Dengan demikian, pengalaman menemukan sendiri konsep tersebut membuat siswa menjadi paham dan konsep tersebut sulit dilupakan, sehingga mereka bisa menyelesaikan permasalahan yang ada mengenai lingkaran tersebut.

Hal ini sesuai dengan pendapat Bruner yang menyebutkan bahwa "siswa hendaknya belajar melalui partisipasi secara aktif dengan konsep dan prinsip-prinsip dan mereka dianjurkan untuk memperoleh pengalaman dan melakukan eksperimen-eksperimen yang mengizinkan mereka menemukan prinsip-prinsip itu sendiri (Dahar: 2001". Senada dengan itu, model investigasi kelompok ini seperti yang dijelaskan pada kajian teori adalah 
sebuah model berparadigma konstruktivisme dimana siswa dibiasakan secara aktif menemukan sendiri konsep dengan cara melakukan kegiatan-kegiatan penyelidikan secara berkelompok sehingga mereka paham dan mengingat lebih lama apa yang telah mereka temukan sendiri sehingga siswa bisa menyelesaikan suatu masalah dengan baik.

\section{PENUTUP}

\section{Kesimpulan}

1. Kemampuan pemecahan masalah matematis siswa yang diajar dengan model kooperatif tipe investigasi kelompok lebih baik secara signifikan daripadasiswa yang diajar dengan pembelajaran konvensional. Dengan skor rata-rata kemampuan pemecahan masalah siswa pada kelas eksperimen 20,59 sedangkan kelas kontrol 10,97

2. Kemampuan pemecahan masalah matematis siswa berkemampuan awal tinggi, sedang, dan rendah yang diajar dengan model kooperatif tipe investigasi kelompok lebih baik secara signifikan daripada siswa berkemampuan awal tinggi yang diajar dengan pembelajaran konvensional. Dengan skor rata-rata kemampuan pemecahan masalah siswa berkemampuan awal tinggi,sedang, dan rendah pada kelas eksperimen masing-masing berturut-turut memperoleh 26,29; 19,38; 18,83 sedangkan kelas kontrol masing-masing kemampuan awal memperoleh 13,$38 ; 10,63 ; 10,18$.

\section{Saran}

1. Bagi Guru, pembelajaran dengan menggunakan model kooperatif tipe investigasi kelompok perlu dijadikan model alternatif dalam rangka meningkatkan kemampuan pemecahan masalah matematis siswa. Dengan model investigasi kelompok, siswa dapat terlibat secara aktif dan dapat menimbulkan minat serta motivasi belajar yang baik, sehingga hasil belajar diharapkan baik pula.

2. Bagi siswa, model pembelajaran kooperatif tipe investigasi kelompok dapat dipandang sebagai model penemuan atau pemecahan masalah yang dilaksanakan secara berkelompok . Dalam pelaksanaan pembelajaran menggunakan model ini lebih memberikan kesempatan kepada siswa untuk terlibat secara berkelompok dalam menyelidiki, menemukan, dan memecahkan masalah. Maka oleh sebab itu, disarankan dalam pelaksanaannya siswa harus benar-benar melaksanakan kegiatan penyelidikan dan guru harus selalu memonitor dan siap membimbing atau 
memberi petunjuk agar kegiatan dan aktivitas siswa dapat sesuai dengan sasaran dan tujuan yang hendak dicapai.

3. Bagi Peneliti selanjutnya, jumlah siswa yang cukup banyak dalam setiap kelas, merupakan salah satu hambatan dalam penerapan model pembelajaran kooperatif tipe investigasi kelompok ini. Maka oleh sebab itu agar aktivitas kelompok berjalan dengan baik dan tidak menimbulkan kebisingan ketika membentuk kelompok sebaiknya kelompok dibentuk sebelum diterapkan model ini dan pembagian kelompok tidak lebih dari 5 orang siswa perkelompok.

\section{DAFTAR PUSTAKA}

Dahar, R. Wilis. (2001).Teori-Teori Belajar \& Pembelajaran. Bandung: Erlangga.

Depdiknas. (2006). Permendiknas SI dan SKL. Jakarta: Sinar Grafika.

Fauzan,Ahmad. (2011). Kemampuan Pemecahan Masalah (Modul 2 Evaluasi Pembelajaran Matematika). Padang: Pascasarjana UNP.

dan Tasman, F. (2012). Laporan Penelitian: Analisis Literasi Matematis Siswa SMP di Sumbar. Padang: Lembaga Penelitian UNP.

Lidinillah, D.A. Muiz. (2009). Investigasi Matematika dalam Pembelajaran Matematika di Sekolah Dasar. Bandung: UPI.

NCTM. (2000). Curriculum and Evaluation Standars for School Mathematics. Reston,VA: NCTM.

PISA. (2009). What Student Know and Can Do. OECHD Publishing.

Setiawan. (2006). Model Pembelajaran Matematika dengan Pendekatan Investigasi. Yogyakarta: PPPG Matematika.

Slavin, Robert E. (2005). Cooperative LearningTeori Riset dan Praktik, Bandung: PT Nusa Media.

Fonna, Mutia. (2013). "Penggunaan Model Pembelajaran Kooperatif Tipe Cooperatif Integrated And Composition untuk Meningkatkan Kemampuan Representasi dan Pemecahan Masalah Matematis Siswa". Tesis tidak diterbitkan. Bandung: Program Pascasarjana UPI. 